\title{
Sponge diversity gradients in marine caves of the eastern Mediterranean
}

\author{
VASILIS GEROVASILEIOU ${ }^{1,2}$ AND ELENI VOULTSIADOU ${ }^{2}$ \\ ${ }^{1}$ Institute of Marine Biology, Biotechnology and Aquaculture, Hellenic Centre for Marine Research, Heraklion, Crete, Greece, \\ ${ }^{2}$ Department of Zoology, School of Biology, Aristotle University of Thessaloniki, Thessaloniki, Greece
}

\begin{abstract}
Although sponges constitute the dominant animal group in marine caves globally, few studies have investigated quantitatively their diversity patterns in this habitat. Regarding Mediterranean marine caves, data describing the structure and diversity gradients of sponge assemblages are available for the north-western basin, while information for the eastern Mediterranean is almost inexistent. In this study, the sponge assemblages in two Aegean marine caves (eastern Mediterranean Sea) with different topography were examined using a non-destructive method. In each cave, three quadrats $(25 \times 25 \mathrm{~cm})$ were photographed at $5 \mathrm{~m}$ intervals, along three transects: one along the ceiling and two along the opposite walls. Per cent coverage for each sponge species was calculated using advanced image processing software. Our analyses revealed a rich sponge assemblage, which consisted of 50 species assigned to eight growth forms. Resemblance analysis for the surveyed caves revealed two major groups of samples corresponding to the shadowy outer and the darker internal cave sectors. However, differences in species composition as well as divergent spatial patterns of species richness, ShannonWiener diversity and morphological diversity were found not only between the caves but also between different transects within each cave. Sponge morphological diversity presented significant positive correlation with species richness and Shannon-Wiener diversity in both caves, suggesting that it could possibly be used as a surrogate measure for describing sponge diversity gradients in Mediterranean caves. Cave topography was found to have a significant effect on the observed diversity patterns and assemblage structure, highlighting the high level of individuality in these unique habitats.
\end{abstract}

Keywords: Porifera, sponges, marine caves, spatial heterogeneity, zonation, diversity, morphological diversity, taxonomic diversity, Eastern Mediterranean, Aegean Sea

Submitted 3 October 2014; accepted 17 April 2015; first published online 5 June 2015

\section{INTRODUCTION}

Porifera is the dominant phylum of sessile animals in marine cave environments (Sará, 1962; Corriero et al., 2000; Bell, 2002). Marine caves are acknowledged for their rich assemblages and have been characterized as 'sponge biodiversity reservoirs' (Gerovasileiou \& Voultsiadou, 2012). The majority of studies concerning cave sponge assemblages provide taxonomic descriptions, with special emphasis on the description of new species, as well as qualitative ecological information (e.g. Vacelet \& Lévi, 1958; Boury-Esnault et al., 1995; Vacelet \& Boury-Esnault, 1996; Pisera \& Vacelet, 2011; Rützler et al., 2014). On the contrary, only a limited number of studies include quantitative data describing the variability of sponge coverage and diversity across the different cave sectors (Russ \& Rützler, 1959; Pouliquen, 1972; Balduzzi et al., 1989; Corriero et al., 2000; Bell, 2002; Parravicini et al., 2010).

Marine cave communities of the Mediterranean Sea have been studied more extensively than in any other marine area with Porifera being the most studied phylum in this ecosystem (Gerovasileiou \& Voultsiadou, 2012, 2014). The majority of the relevant studies have taken place in shallow

Corresponding author:

V. Gerovasileiou

Email: vgerovas@hcmr.gr caves along the north-western and central Mediterranean rocky coasts. Interestingly, limited research in marine caves of the eastern basin has brought to light several new sponge species with a narrow distribution range (Gerovasileiou et al., 2015a and references therein). Information on the ecology of these species is scarce, while quantitative data describing the structure and diversity gradients of sponge assemblages in eastern Mediterranean marine caves is practically non-existent. This becomes critical given that the latter area is subjected to severe temperature alterations attributed to global climate change (Bianchi \& Morri, 2003), as well as to biological invasions (Gerovasileiou et al., 2015b). Marine cave habitats are protected by the European and Mediterranean legislative framework due to their unique biological wealth (92/43/EEC and UNEP-MAP-RAC/SPA, 2015).

The study of marine caves involves several difficulties, related mainly to underwater fieldwork due to practical restrictions in space, time and visibility conditions. Therefore, the use of rapid and non-destructive photographic methods constitutes a valuable advantage for the quantitative study of cave communities. The main disadvantage of photographic methods are potential limitations as regards taxonomic identification of species (Bianchi et al., 2004), especially in areas where information on diversity is limited and light conditions are poor, which could affect animal colouration. To address such problems, a surrogate diversity measure might be a solution. Sponge morphological diversity (MD) is a good option, since it can be easily assessed during underwater 
fieldwork, even by non-specialists, and thus could be used in monitoring programmes (Bell \& Barnes, 2001; Bell, 2007; Schönberg \& Fromont, 2013). Bell \& Barnes (2001) showed that sponge MD could serve as a qualitative predictor of species diversity in open rocky habitats but no significant correlation was found in tropical marine caves (Bell \& Barnes, 2002). The functionality of this model has not been examined either in temperate marine caves or in the Mediterranean ecosystem. The application of a photographic method along with diversity surrogates in eastern Mediterranean caves could both accelerate our knowledge of sponge communities in this area and check the effectiveness of these cost- and timesaving methods.

Under this scope, the aim of this study was to provide a quantitative description of sponge assemblages in two distinct marine caves of the eastern Mediterranean Sea, using nondestructive methods in order to examine (i) the specific composition of sponge assemblages and (ii) the spatial variability of sponge diversity in various cave microhabitats using several different diversity measures.

\section{MATERIALS AND METHODS}

\section{Study areas}

Two marine caves of the Aegean Sea (north-eastern Mediterranean) were studied. The caves represent distinct types, according to the morphological categorization proposed by Riedl (1966), reflecting differences in the two critical abiotic factors, which generate ecological zonation in cave communities: (i) light and (ii) water movement. Both caves are situated off Lesvos Island, on the rocky islets of Agios Vasilios and Fara Bay.

The entrance of Agios Vasilios cave is located at a depth range of 24-40 $\mathrm{m}$ (average $32 \mathrm{~m}$ ). Its large dimensions ( $16 \mathrm{~m}$ high and $7 \mathrm{~m}$ wide) result in a relatively well-lit zone within the first $10-15 \mathrm{~m}$, giving the impression of a large cavern. The cave becomes narrower towards the interior, resembling a large blind funnel (Figure $1 \mathrm{~A}, \mathrm{~B}$ ). At a distance of $22 \mathrm{~m}$ from the entrance, the cave leads to a narrow dark tunnel ascending up to a depth of $15 \mathrm{~m}$. Within the framework of this study only the first $20 \mathrm{~m}$ of this cave were surveyed.

The entrance of Fara cave is located at a depth of $18 \mathrm{~m}$, while the average depth of the cave interior is $14 \mathrm{~m}$. At its inner end, $32 \mathrm{~m}$ from the entrance, a narrow fissure connects this cave to a second smaller one on the other side of the islet; it actually constitutes a submerged tunnel (Figure ${ }_{1} \mathrm{C}, \mathrm{D}$ ) penetrating the islet. The caves were mapped and threedimensional depictions of their morphology were produced using 'cavetopo' software (Gerovasileiou et al., 2013).

\section{Quantitative and qualitative sampling}

Sampling was implemented with scuba diving. The sponge assemblages of the two caves were studied with $25 \times 25 \mathrm{~cm}$ photoquadrats, as proposed by Kipson et al. (2011) for the study of sciaphilic sessile benthos. Three randomly placed replicate quadrats were photographed at $5 \mathrm{~m}$ intervals, from the entrance to the interior of the two caves, along three transects: one along the ceiling (C) and two along the opposite vertical walls (R: right and L: left). For comparison purposes, sampling was also performed on the adjacent side walls of the outer zone (Out) of the conic entrance of Fara cave, while this was not necessary for the entrance of Agios Vasilios cave, due to its specific morphology described above. In total, 72 quadrats were photographed in Fara and 45 in Agios Vasilios cave.

Additionally, about 80 sponge specimens were photographed in situ and collected from different zones of the two caves in order to identify the sponges present in the photoquadrats. Sponge specimens and spicule preparations were identified based on a large number of publications, in accordance with the classification proposed in Systema Porifera (Hooper \& Van Soest, 2002) and the World Porifera Database (Van Soest et al., 2015).

\section{Image processing}

Biotic per cent coverage of sponges present on the 117 photoquadrats was calculated using photoQuad; this advanced image processing software is dedicated to underwater ecological applications integrating various methods and tools for the accurate calculation of species coverage (Trygonis \& Sini, 2012). In each photoquadrat, the external outline around every sponge specimen was defined manually in detail using freehand drawing tools (i.e. freehand region method). All defined specimen surfaces (regions of interest) were assigned to the corresponding sponge species based on the in situ photographs of the identified qualitative samples. Furthermore, sponge specimens in each photoquadrat were

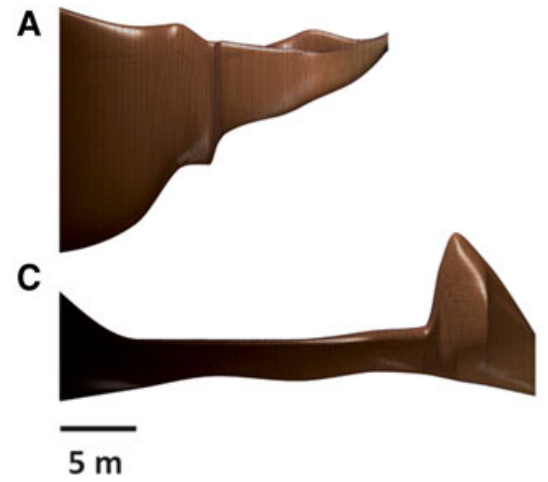

B
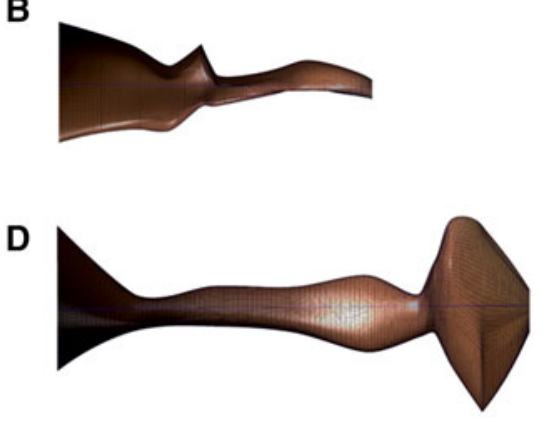

Fig. 1. Scaled three-dimensional models of Agios Vasilios (A: lateral view, B: top view) and Fara cave (C: lateral view, D: top view) produced with 'cavetopo' software (Gerovasileiou et al., 2013). 
assigned to eight morphological types, according to the relevant bibliography (i.e. Boury-Esnault \& Rützler, 1997; Bell \& Barnes, 2001, 2002): massive, massive-tubular, arborescent, globular, encrusting, clathrate, boring and repent. Per cent coverage for every sponge species and morphological type was calculated automatically by photoQuad.

\section{Assemblage structure and statistical analyses}

Multivariate resemblance analysis of the quadrats photographed was performed separately for each marine cave with multidimensional scaling (MDS), based on the BrayCurtis similarity index (fourth root transformed coverage data). The contribution of sponge species to Bray-Curtis dissimilarity among the resulting sample groups was estimated with SIMPER (SIMilarity PERcentages).

In order to assess the effect of internal cave topography on the sponge assemblage structure of each cave, two-way PERMANOVA was performed for two topographic factors: (i) Distance from entrance (Di), fixed with eight levels for Fara (Out, 0, 5, 10, 15, 20, 25 and $30 \mathrm{~m}$ ) and five levels for Agios Vasilios cave (0, 5, 10, 15 and $20 \mathrm{~m}$ ); and (ii) Position (Po), fixed with three levels for both caves (C: cave ceiling, L: left wall, R: right wall). The design was balanced with three replicates at each level of Po and crossed provided all levels of Po could be found at every level of Di and vice versa (Anderson et al., 2008).

Five diversity indices were calculated for the sponge fauna of each photoquadrat, based on coverage data: species richness $(\mathrm{S})$, Shannon-Wiener diversity (H'), species evenness (J'), taxonomic (TD) and morphological diversity (MD). For the estimation of taxonomic diversity, taxonomic distinctness $\left(\Delta^{*}\right)$ was chosen as a measure of taxonomic relatedness (Warwick \& Clarke, 1995; Clarke \& Warwick, 1998). Morphological diversity was calculated with the ShannonWiener function, as proposed by Maldonado \& Young (1996). Spearman's rank correlation coefficient was used to investigate relationships of MD with $\mathrm{S}$ and $\mathrm{H}$ '.

In order to assess the effect of the two aforementioned topographic factors (Di and $\mathrm{Po}$ ) on the sponge diversity of the two caves, two-way ANOVA was performed for each diversity measure separately. Diversity data were checked for normality and homogeneity of variance with the Kolmogorov-Smirnov and Levene's tests, respectively, and were properly transformed, when these assumptions were not met. The Tukey's range post-hoc test was used in cases of significant differences between samples.

All statistical analyses were performed with the IBM SPSS Statistics 21 and PRIMER-E v6 software packages (Clarke \& Gorley, 2006), using the extracted sponge coverage data.

\section{RESULTS}

In total, 50 sponge species classified into three classes, 11 orders and 27 families were identified. Out of these, 46 species were recorded in Fara cave, 32 in Agios Vasilios cave and 28 were found in both caves (Table 1). One of the species found, Ircinia paucifilamentosa, is endemic to the Aegean ecoregion. In Fara cave, the dominant species in terms of spatial coverage were: Dendroxea lenis, Spirastrella cunctatrix, Agelas oroides, Phorbas tenacior, Diplastrella bistellata and Hexadella pruvoti. In Agios Vasilios cave, the dominant sponges were: Spirastrella cunctatrix, Plakina bowerbanki, Dendroxea lenis, Hexadella racovitzai, $H$. pruvoti and Aplysina aerophoba. In the latter cave, the orders Homosclerophorida (24.6\%) and Verongida (23.2\%) prevailed, while in the former these taxa occupied a notably smaller proportion $(<5 \%)$ of total sponge coverage.

Multivariate resemblance analysis revealed two major groups of photoquadrat samples in both caves, one corresponding to the samples taken close to the cave entrance and the other to those of the internal cave sectors (Figure 2). Photoquadrats taken at different positions at the same distance level of Fara cave were often placed in different sub-groups (e.g. 5 and $10 \mathrm{~m}$ left wall $v s$ right wall samples) or even major groups (e.g. photoquadrats from the $15 \mathrm{~m}$ ceiling zone were placed with the inner group, while the corresponding wall samples with the outer group). The Distance and Position factors, and their combined action had a significant effect on the assemblage structure in both caves (Table 2). However, pair-wise tests showed no significant differences in similarity among specific successive distance levels (i.e. 5 and $10 \mathrm{~m} ; 25$ and $30 \mathrm{~m}$ in Fara; o and $5 \mathrm{~m}$ in Agios Vasilios cave). Similarity of samples at different positions of each distance level generally increased towards the interior in both caves (Figure 3).

SIMPER analysis between the outer and inner groups of Fara cave showed that nine species (Spirastrella cunctatrix, Agelas oroides, Dendroxea lenis, Phorbas tenacior, Hexadella pruvoti, Eurypon sp., Diplastrella bistellata, Plakina bowerbanki and Haliclona mucosa) contributed 63\% to the BrayCurtis dissimilarity index. Similarly, in Agios Vasilios cave, Spirastrella cunctatrix, Plakina bowerbanki, Eurypon sp., Aplysina aerophoba, Dendroxea lenis, Oscarella tuberculata, Hexadella pruvoti, Phorbas tenacior and Timea unistellata contributed $63 \%$ to the Bray-Curtis dissimilarity index.

Concerning spatial variability of diversity, the $\mathrm{S}$ and $\mathrm{H}^{\prime}$ indices were generally higher in Agios Vasilios cave, at most distance levels. Overall, the examined diversity measures showed the same general trend in both caves (Figure $4 \mathrm{~A}, \mathrm{E}$ ). Specifically, in Fara cave, an increase was observed from the entrance to the first $5 \mathrm{~m}$, then a decrease towards the dark inner chamber, where few encrusting species prevailed $(20 \mathrm{~m})$, and finally an increase at the end of the chamber, close to the fissure that connects the cave to the other side of the islet $(30 \mathrm{~m})$; in this cave area, few massive and clathrate species developed, in addition to the typical encrusting sponges of the dark cave sectors. In Agios Vasilios cave, a general decrease was observed, with $\mathrm{S}$ and $\mathrm{H}^{\prime}$ presenting an increase at the $15 \mathrm{~m}$ distance level.

This general pattern was differentiated when the two walls and the ceiling of the surveyed caves were examined separately. Thus, in Fara cave, S, H' and MD on the opposite vertical walls followed the general trend described above (Figure $4 \mathrm{~B}$, C). Contrasting spatial patterns were observed for the opposite vertical walls of Agios Vasilios cave. Thus, on the left wall (Figure ${ }_{4} \mathrm{~F}$ ) S, H' and MD gradually decreased towards the dark interior. On the right cave wall (Figure ${ }_{4} \mathrm{~F}$ ), these indices gained their highest values $15 \mathrm{~m}$ away from the entrance.

Along the ceiling of Fara cave, all diversity measures decreased towards the middle sector $(15 \mathrm{~m})$ but presented an increasing trend thereafter (Figure $4 \mathrm{D}$ ). However, diversity values on the ceiling were lower compared with those on the vertical walls at the corresponding distance levels, 
Table 1. Morphotype, per cent sponge coverage (C), distribution (Di) across the horizontal axis (OUT: outer zone, o-30: distance from entrance in metres) and position (Po) of the sponge species recorded in the surveyed caves. EN, encrusting; MA, massive; MA-TU, massive-tubular; AR, arborescent; CLA, clathrate; BO, boring; RE, repent; GLO, globular; C, cave ceiling; L, left wall; R, right wall.

\begin{tabular}{|c|c|c|c|c|c|c|c|}
\hline & \multirow[b]{2}{*}{ Morphotype } & \multicolumn{3}{|l|}{ Fara } & \multicolumn{3}{|c|}{ Agios Vasilios } \\
\hline & & C (\%) & Di & Po & $\mathrm{C}(\%)$ & $\mathrm{Di}$ & Po \\
\hline \multicolumn{8}{|l|}{ Class Calcarea } \\
\hline \multicolumn{8}{|l|}{ Order Clathrinida } \\
\hline \multicolumn{8}{|l|}{ Family Clathrinidae } \\
\hline Clathrina sp. & CLA & 0.2 & $0-30$ & $\mathrm{C}, \mathrm{L}, \mathrm{R}$ & $<0.1$ & 15 & $\mathrm{C}, \mathrm{L}$ \\
\hline \multicolumn{8}{|l|}{ Class Demospongiae } \\
\hline \multicolumn{8}{|l|}{ Order Agelasida } \\
\hline \multicolumn{8}{|l|}{ Family Agelasidae } \\
\hline Agelas oroides (Schmidt, 1864) & MA, MA-TU & 14.5 & OUT -20 & $\mathrm{C}, \mathrm{L}, \mathrm{R}$ & 0.8 & $0-10$ & $\mathrm{C}, \mathrm{L}$ \\
\hline \multicolumn{8}{|l|}{ Order Astrophorida } \\
\hline \multicolumn{8}{|l|}{ Family Ancorinidae } \\
\hline Jaspis johnstonii (Schmidt, 1862) & $\mathrm{EN}$ & 1.4 & $5-25$ & $\mathrm{~L}, \mathrm{R}$ & & & \\
\hline \multicolumn{8}{|l|}{ Family Geodiidae } \\
\hline Penares euastrum (Schmidt, 1868) & MA & 2.4 & $5-15$ & $\mathrm{~L}, \mathrm{R}$ & 2.9 & $0-15$ & $\mathrm{C}, \mathrm{L}, \mathrm{R}$ \\
\hline \multicolumn{8}{|l|}{ Order Chondrosida } \\
\hline \multicolumn{8}{|l|}{ Family Chondrillidae } \\
\hline Thymosiopsis cuticulatus Vacelet \& Perez, 1998 & EN & 1.4 & $5-15$ & $\mathrm{~L}, \mathrm{R}$ & & & \\
\hline Order Dendroceratida & & & & & & & \\
\hline Family Darwinellidae & & & & & & & \\
\hline Aplysilla rosea (Barrois, 1876) & EN & 0.1 & OUT -5 & $\mathrm{C}, \mathrm{L}$ & 0.1 & $0-15$ & $\mathrm{C}, \mathrm{L}, \mathrm{R}$ \\
\hline Order Dictyoceratida & & & & & & & \\
\hline Family Dysideidae & & & & & & & \\
\hline Dysidea fragilis (Montagu, 1814) & MA & 0.5 & 10 & $\mathrm{~L}$ & & & \\
\hline Pleraplysilla spinifera (Schulze, 1879) & $\mathrm{EN}$ & 0.6 & OUT -15 & $\mathrm{C}, \mathrm{L}, \mathrm{R}$ & 1.6 & $0-15$ & $\mathrm{C}, \mathrm{L}, \mathrm{R}$ \\
\hline Family Irciniidae & & & & & & & \\
\hline Ircinia oros (Schmidt, 1864$)$ & MA & 0.3 & o & $\mathrm{L}$ & & & \\
\hline Ircinia paucifilamentosa Vacelet, 1961 & MA & 2.5 & $15-25$ & $\mathrm{~L}, \mathrm{R}$ & 0.7 & $0-10$ & $\mathrm{C}, \mathrm{L}$ \\
\hline Ircinia variabilis (Schmidt, 1862) & MA & 0.8 & 10 & $\mathrm{R}$ & & & \\
\hline Sarcotragus foetidus Schmidt, 1862 & MA & & & & 0.2 & 5 & $\mathrm{C}$ \\
\hline Family Spongiidae & & & & & & & \\
\hline Spongia (Spongia) virgultosa (Schmidt, 1868) & $\mathrm{RE}$ & 0.1 & OUT-o & $\mathrm{R}$ & & & \\
\hline Family Thorectidae & & & & & & & \\
\hline Fasciospongia cavernosa (Schmidt, 1862) & MA & $<0.1$ & OUT -5 & $\mathrm{C}, \mathrm{L}$ & $<0.1$ & 5 & $\mathrm{C}$ \\
\hline Order Hadromerida & & & & & & & \\
\hline Family Clionaidae & & & & & & & \\
\hline Cliona celata Grant, 1826 & $\mathrm{BO}$ & 0.1 & OUT -10 & C, L, R & & & \\
\hline Cliona schmidti (Ridley, 1881) & $\mathrm{BO}$ & 0.1 & OUT -5 & C, L, R & $<0.1$ & 0 & $\mathrm{C}$ \\
\hline Cliona viridis (Schmidt, 1862) & $\mathrm{BO}$ & 0.3 & OUT-o & $\mathrm{C}, \mathrm{L}$ & & & \\
\hline Family Spirastrellidae & & & & & & & \\
\hline Diplastrella bistellata (Schmidt, 1862) & EN & 6 & $15-30$ & $\mathrm{C}, \mathrm{L}, \mathrm{R}$ & & & \\
\hline Spirastrella cunctatrix Schmidt, 1868 & EN & 16.1 & OUT -15 & C, L, R & 14.1 & $0-10$ & C, L, R \\
\hline Family Suberitidae & & & & & & & \\
\hline Aaptos aaptos (Schmidt, 1864) & EN & 0.1 & 5 & $\mathrm{C}$ & & & \\
\hline Terpios gelatinosa (Bowerbank, 1866) & $\mathrm{EN}$ & $<0.1$ & OUT -15 & $\mathrm{~L}, \mathrm{R}$ & $<0.1$ & $0-15$ & $\mathrm{R}$ \\
\hline Family Tethyidae & & & & & & & \\
\hline Tethya aurantium (Pallas, 1766) & GLO & 0.2 & 0 & $\mathrm{R}$ & & & \\
\hline Family Timeidae & & & & & & & \\
\hline Timea unistellata (Topsent, 1892) & $\mathrm{EN}$ & 0.1 & 15 & $\mathrm{R}$ & 5.9 & $0-20$ & $\mathrm{C}, \mathrm{L}, \mathrm{R}$ \\
\hline Order Halichondrida & & & & & & & \\
\hline Family Axinellidae & & & & & & & \\
\hline Axinella cannabina (Esper, 1794) & AR & 0.4 & $5-10$ & $\mathrm{~L}$ & & & \\
\hline Axinella damicornis (Esper, 1794) & MA & 1.6 & OUT -10 & $\mathrm{~L}, \mathrm{R}$ & 0.7 & $0-15$ & $\mathrm{C}, \mathrm{L}, \mathrm{R}$ \\
\hline Axinella verrucosa (Esper, 1794) & AR & 0.8 & $5-10$ & $\mathrm{~L}$ & & & \\
\hline Family Dictyonellidae & & & & & & & \\
\hline Acanthella acuta Schmidt, 1862 & MA & 1.8 & OUT -10 & $\mathrm{~L}, \mathrm{R}$ & & & \\
\hline Dictyonella incisa (Schmidt, 1880) & MA & 0.4 & OUT -10 & $\mathrm{~L}, \mathrm{R}$ & $<0.1$ & 15 & $\mathrm{R}$ \\
\hline Family Heteroxyidae & & & & & & & \\
\hline Myrmekioderma spelaeum (Pulitzer-Finali, 1983) & MA & $<0.1$ & 30 & $\mathrm{C}$ & & & \\
\hline Order Haplosclerida & & & & & & & \\
\hline Family Chalinidae & & & & & & & \\
\hline Dendroxea lenis (Topsent, 1892) & EN & 18.3 & $0-30$ & $\mathrm{C}, \mathrm{L}, \mathrm{R}$ & 12.1 & $0-15$ & $\mathrm{C}, \mathrm{L}, \mathrm{R}$ \\
\hline
\end{tabular}


Table 1. Continued

\begin{tabular}{|c|c|c|c|c|c|c|c|}
\hline & \multirow[b]{2}{*}{ Morphotype } & \multicolumn{3}{|l|}{ Fara } & \multicolumn{3}{|c|}{ Agios Vasilios } \\
\hline & & $\mathrm{C}(\%)$ & Di & Po & $\mathrm{C}(\%)$ & $\mathrm{Di}$ & Po \\
\hline Haliclona (Halichoclona) fulva (Topsent, 1893) & $\mathrm{EN}$ & 0.3 & $15-30$ & $\mathrm{~L}, \mathrm{R}$ & 0.2 & o & $\mathrm{L}$ \\
\hline Haliclona (Soestella) mucosa (Griessinger, 1971) & $\mathrm{EN}$ & 1.6 & OUT -30 & $\mathrm{C}, \mathrm{L}, \mathrm{R}$ & 0.6 & $0-10$ & $\mathrm{C}, \mathrm{L}, \mathrm{R}$ \\
\hline $\begin{array}{l}\text { Haliclona sp. } \\
\text { Family Petrosiidae }\end{array}$ & $\mathrm{EN}$ & $<0.1$ & o & $\mathrm{R}$ & & & \\
\hline $\begin{array}{l}\text { Petrosia (Petrosia) ficiformis (Poiret, 1789) } \\
\text { Order Poecilosclerida } \\
\text { Family Crellidae }\end{array}$ & MA & 1.4 & OUT -15 & $\mathrm{C}, \mathrm{L}, \mathrm{R}$ & & & \\
\hline $\begin{array}{l}\text { Crella sp. } \\
\text { Family Hymedesmiidae }\end{array}$ & $\mathrm{EN}$ & & & & 0.2 & 15 & $\mathrm{R}$ \\
\hline $\begin{array}{l}\text { Phorbas tenacior (Topsent, 1925) } \\
\text { Family Raspailiidae }\end{array}$ & $\mathrm{EN}$ & 14 & OUT -15 & C, L, R & $4 \cdot 3$ & $0-5$ & $\mathrm{C}, \mathrm{L}, \mathrm{R}$ \\
\hline Eurypon clavatum (Bowerbank, 1866) & $\mathrm{EN}$ & 0.2 & 15 & $\mathrm{C}$ & 0.1 & $15-20$ & $\mathrm{C}$ \\
\hline Eurypon sp. & $\mathrm{EN}$ & 1.6 & $10-30$ & C, L, R & $5 \cdot 3$ & $0-20$ & $\mathrm{C}, \mathrm{L}, \mathrm{R}$ \\
\hline $\begin{array}{l}\text { Raspaciona aculeata (Johnston, 1842) } \\
\text { Order Verongida } \\
\text { Family Aplysinidae }\end{array}$ & $\mathrm{EN}$ & 1 & $5-15$ & $\mathrm{C}, \mathrm{L}, \mathrm{R}$ & 2.6 & $0-15$ & $\mathrm{C}, \mathrm{L}, \mathrm{R}$ \\
\hline $\begin{array}{l}\text { Aplysina aerophoba Nardo, } 1833 \\
\text { Family Ianthellidae }\end{array}$ & MA, MA-TU & & & & 6.3 & $0-15$ & $\mathrm{C}, \mathrm{L}, \mathrm{R}$ \\
\hline Hexadella pruvoti Topsent, 1896 & $\mathrm{EN}$ & 4.5 & OUT -30 & $\mathrm{C}, \mathrm{L}, \mathrm{R}$ & 6.5 & $0-15$ & $\mathrm{C}, \mathrm{L}, \mathrm{R}$ \\
\hline Hexadella racovitzai Topsent, 1896 & $\mathrm{EN}$ & 0.2 & 10 & $\mathrm{C}, \mathrm{R}$ & 10.3 & $0-15$ & C, L, R \\
\hline $\begin{array}{l}\text { Hexadella sp. } \\
\text { Class Homoscleromorpha } \\
\text { Order Homosclerophorida } \\
\text { Family Oscarellidae }\end{array}$ & $\mathrm{EN}$ & 0.4 & $10-25$ & $\mathrm{C}, \mathrm{L}, \mathrm{R}$ & $<0.1$ & 15 & $\mathrm{~L}$ \\
\hline Oscarella balibaloi Pérez et al., 2011 & $\mathrm{EN}$ & 0.1 & $0-5$ & $\mathrm{C}, \mathrm{R}$ & 2.7 & $0-5$ & $\mathrm{~L}, \mathrm{R}$ \\
\hline Oscarella microlobata Muricy et al., 1996 & $\mathrm{EN}$ & 1 & $20-30$ & $\mathrm{C}, \mathrm{L}, \mathrm{R}$ & 0.1 & 15 & $\mathrm{C}$ \\
\hline Oscarella tuberculata (Schmidt, 1868) & $\mathrm{EN}$ & 0.1 & 10 & $\mathrm{R}$ & 5.9 & $0-15$ & C, L, R \\
\hline $\begin{array}{l}\text { Oscarella jarrei Boury-Esnault et al., } 1995 \\
\text { Family Plakinidae }\end{array}$ & $\mathrm{EN}$ & 0.2 & $0-10$ & $\mathrm{C}, \mathrm{R}$ & $<0.1$ & $0-5$ & $\mathrm{~L}, \mathrm{R}$ \\
\hline Plakina bowerbanki (Sarà, 1960) & $\mathrm{EN}$ & 1.6 & $20-30$ & $\mathrm{C}, \mathrm{L}, \mathrm{R}$ & 13.6 & $0-20$ & $\mathrm{C}, \mathrm{L}, \mathrm{R}$ \\
\hline Plakina sp. & $\mathrm{EN}$ & 0.8 & $0-30$ & $\mathrm{C}, \mathrm{L}, \mathrm{R}$ & & & \\
\hline Plakina trilopha Schulze, 1880 & $\mathrm{EN}$ & & & & 2.2 & $0-20$ & $\mathrm{C}, \mathrm{L}, \mathrm{R}$ \\
\hline
\end{tabular}

with the exception of the entrance and internal cave sector. A different pattern was found for the ceiling of Agios Vasilios cave (Figure $4 \mathrm{H}$ ). Species richness and $\mathrm{H}^{\prime}$ decreased towards the intermediate zone $(10 \mathrm{~m})$, increased again at $15 \mathrm{~m}$ from the entrance, and gained their lowest values in the inner dark zone. Morphological diversity and J' decreased towards the cave interior, though not statistically significantly (Table 3).

In Fara cave, $\mathrm{S}$ was considerably higher on the walls (L: 34 , $\mathrm{R}: 36)$ than on the ceiling (C: 27), while in Agios Vasilios approximately the same number of species was found in all positions (C: 25, L: 24, R: 21).

Morphological diversity was generally higher in Fara where all eight sponge morphotypes were found (C: 5, L: 6, R: 7), while five morphotypes were recorded in Agios Vasilios (C: 5, L: 4, R: 3). Morphological diversity values were found to be positively correlated with $\mathrm{S}$ and $\mathrm{H}^{\prime}$ indices in the two caves; however, a higher correlation coefficient value was found in Fara cave (Table 4 ).

Taxonomic distinctness $\left(\Delta^{*}\right)$ showed a slight increasing trend towards the inner zone of both caves (Figure 5). Interestingly, on the ceiling transect it steeply decreased $15 \mathrm{~m}$ away from the entrance; however, statistically significant variance was found only in Fara cave (Table 3 ).

Results of the two-way ANOVA showed that Distance from the entrance as well as its interaction with Position had a significant effect on the variance of all diversity measures in Fara but only of $\mathrm{S}$ and $\mathrm{H}^{\prime}$ in Agios Vasilios (Table 3). On the other hand, Position seemed to have a significant effect only on $\mathrm{S}$ in the former and J' in the latter cave.

\section{DISCUSSIDN}

This study provided a first quantitative description of the diversity and spatial distribution of sponge assemblages in eastern Mediterranean marine caves, allowing recognition of distinct patterns. Analyses revealed that different sponge species dominated in each cave (e.g. Agelas oroides was abundant in Fara but was rare in Agios Vasilios). A considerable proportion of the recorded species (44\%) were found in only one cave, although both were located in the same geographic area. This could be explained by the fact that the studied caves are characterized by different topographic features. Previous studies have underlined the high level of individuality of marine cave assemblages; different sessile species might dominate in equivalent sectors of even neighbouring caves with similar morphology (Bussotti et al., 2006). It should also be taken into account that the two caves are situated on different islets. Marine caves are considered fragmented habitats (Harmelin et al., 1985) and insular caves have been characterized as double-isolated ecosystems (Bibiloni et al., 1989). A recent overview of the sponge diversity in Mediterranean marine caves found that $67 \%$ of the species 
A

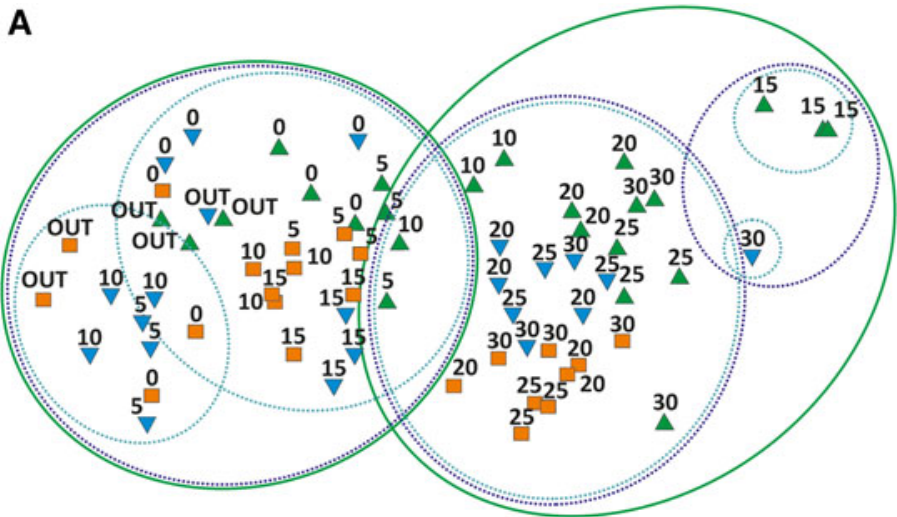

B

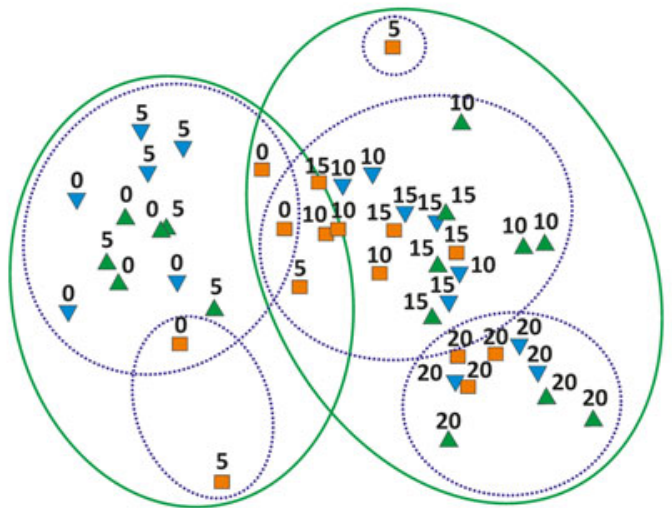

2D Stress: 0.13

Position

$\Delta$ Ceiling

$\nabla$ Left wall

$\square$ Right wall

Similarity

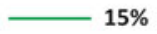

$20 \%$ $30 \%$

Fig. 2. Resemblance of sponge assemblages demonstrated as MDS plots for Fara (A) and Agios Vasilios caves (B). Numbers indicate distance from cave entrance.

were recorded in fewer than five caves and $34.5 \%$ in only one cave (Gerovasileiou \& Voultsiadou, 2012). Furthermore, photographic approaches often underestimate the presence of cryptobiotic species, which may constitute a significant element of cave sponge assemblages (Balduzzi et al., 1989; Corriero et al., 2000). This has been witnessed during detailed sampling in the two Aegean marine caves considered, which revealed the presence of several species that were not encountered in the photoquadrats (Gerovasileiou \& Voultsiadou, 2012).

Table 2. Summary of results of two-way PERMANOVA with the Distance (Di) and Position (Po) as factors for the studied caves. Analyses were performed on fourth root transformed coverage data, based on the Bray-Curtis similarity index (** significance at the 0.01 level).

\begin{tabular}{lrllll}
\hline Source of variability & $\boldsymbol{d} . f$. & SS & MS & \multicolumn{1}{l}{$\boldsymbol{F}$} & $\boldsymbol{P}$ \\
\hline Fara cave & & & & & \\
Position (Po) & 7 & 85,633 & 12,233 & 9.0503 & $0.001^{* *}$ \\
Distance (Di) & 2 & 14,319 & 7159.3 & 5.2966 & $0.001^{* *}$ \\
Di $\times$ Po & 14 & 61,342 & 4381.6 & 3.2415 & $0.001^{* *}$ \\
Residual & 48 & 64,881 & 1351.7 & & \\
Total & 71 & $2.26 \times 10^{5}$ & & & \\
Agios Vasilios cave & & & & & \\
Distance (Di) & 4 & 63,265 & 15,816 & 18.586 & $0.001^{* *}$ \\
Position (Po) & 2 & 6394.8 & 3197.4 & 3.7574 & $0.001^{* *}$ \\
Di $\times$ Po & 8 & 14,557 & 1819.7 & 2.1384 & $0.001^{* *}$ \\
Residual & 30 & 25,529 & 850.96 & & \\
Total & 44 & $1.10 \times 10^{5}$ & & & \\
\hline & & & & & \\
\hline
\end{tabular}

Resemblance analysis for the surveyed caves revealed two major groups of samples corresponding to the shadowy outer and the darker internal cave sectors, in accordance with pioneer studies (Sará, 1961). The dissimilarity among these two cave sectors in Fara cave was attributed to different species, which (according to the results of SIMPER analysis) could be assigned to the following categories: (i) species found exclusively in the outer sector (Spirastrella cunctatrix and Phorbas tenacior), (ii) species with higher coverage in the outer sector (Agelas oroides and Hexadella pruvoti), (iii) species with higher coverage in the inner sector (Dendroxea lenis, Eurypon sp., Diplastrella bistellata and Haliclona $m u \cos a$ ), and (iv) species found exclusively in the inner sector (Plakina bowerbanki). Respectively, in Agios Vasilios, the following categories were responsible for cave sector dissimilarity: (i) species with higher coverage in the outer

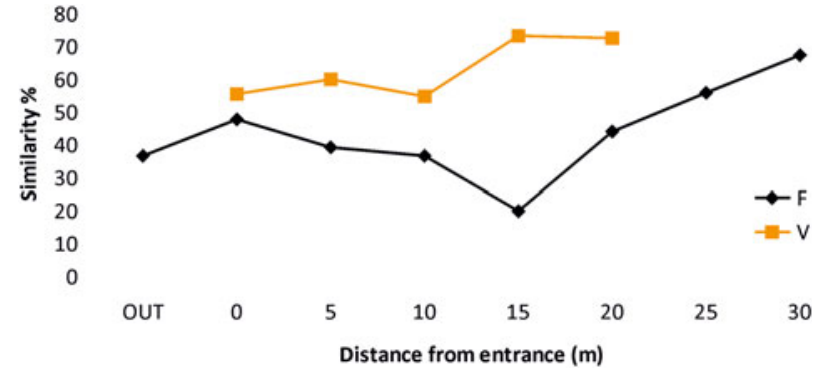

Fig. 3. Similarity (Bray-Curtis index) of samples between the three positions (ceiling and two vertical walls) at each distance level towards the interior of Fara (F) and Agios Vasilios cave (V). 
A

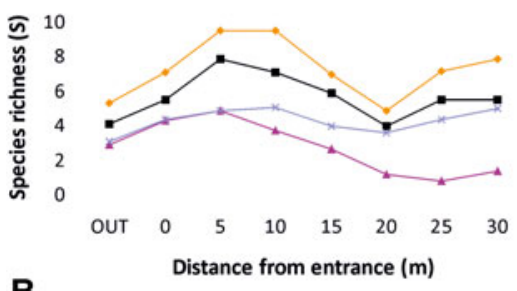

B

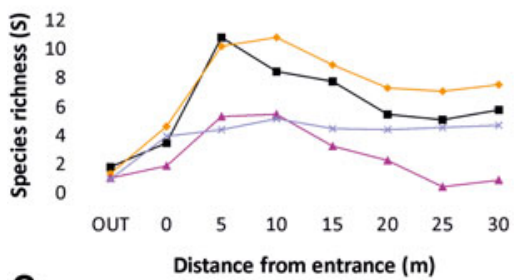

C

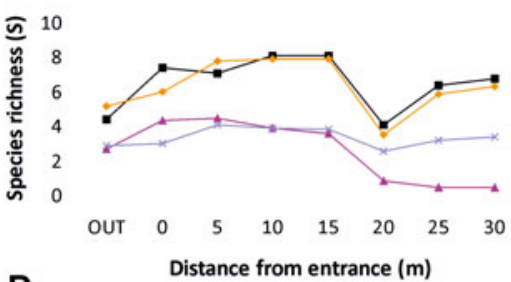

D

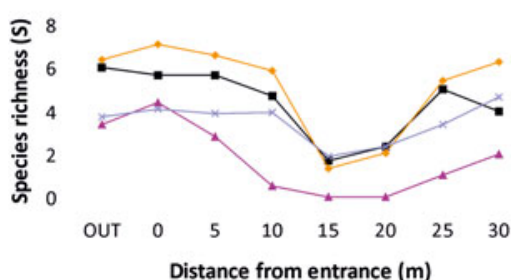

E

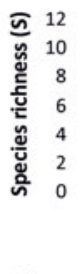

$\mathbf{F}$

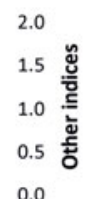

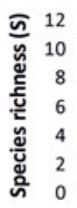

G

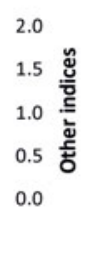

H

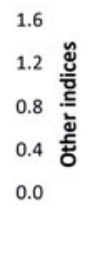

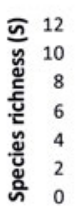

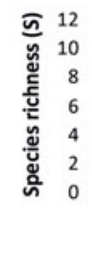

Agios Vasilios cave

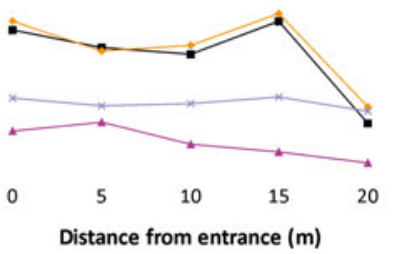

2.0

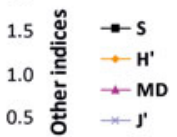

0.0

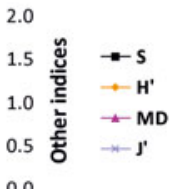

$\begin{array}{lllll}0 & 5 & 10 & 15 & 20\end{array}$

Distance from entrance $(\mathrm{m})$

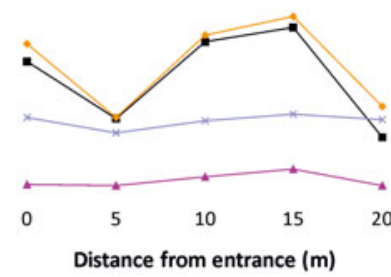

2.0
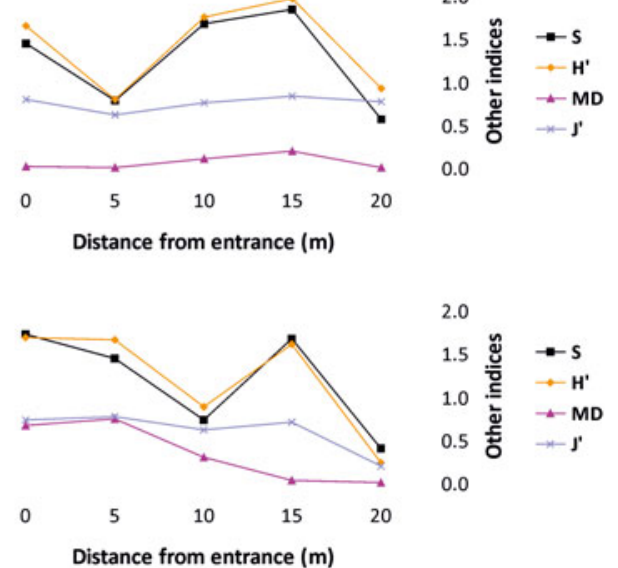

20

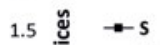

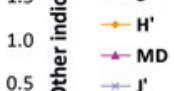

0.0

Fig. 4. Diversity indices across the horizontal axis (OUT: outer zone, o-30: distance from entrance in metres) of Fara (A: total, B: left wall, C: right wall, D: ceiling) and Agios Vasilios (E: total, F: left wall, G: right wall, H: ceiling) caves.

sector (Spirastrella cunctatrix, Aplysina aerophoba, Oscarella tuberculata, Hexadella pruvoti, and Phorbas tenacior), (ii) species with higher coverage in the inner sector (Eurypon sp., Dendroxea lenis and Timea unistellata), and (iii) species found exclusively in the inner sector (Plakina bowerbanki). Previous studies have also reported on the preference of some species (e.g. Dendroxea lenis, Diplastrella bistellata and Timea unistellata) for dark conditions (Cinelli et al., 1977; Bibiloni et al., 1989; Corriero et al., 2000).

Besides the commonly examined effect of horizontal distance from entrance on cave communities, this study investigated the effect of position at each distance level (i.e. ceiling

Table 3. Summary of results of two-way ANOVA with the Distance (Di) and Position (Po) factors for each diversity measure of the studied caves. S, species richness; H', Shannon-Wiener diversity; MD, morphological diversity; J', species evenness; $\Delta^{*}$, taxonomic distinctness, ${ }^{* *}$ significance at the 0.01 level, ${ }^{*}$ significance at the 0.05 level.

\begin{tabular}{|c|c|c|c|c|c|c|c|c|c|c|c|}
\hline \multirow{2}{*}{ Source of variability } & \multirow[b]{2}{*}{ d.f. } & \multicolumn{2}{|l|}{$\mathbf{S}$} & \multicolumn{2}{|l|}{$\mathbf{H}^{\prime}$} & \multicolumn{2}{|l|}{ MD } & \multicolumn{2}{|l|}{$\mathrm{J}^{\prime}$} & \multicolumn{2}{|l|}{$\boldsymbol{\Delta}^{*}$} \\
\hline & & $F$ & $P$ & $F$ & $P$ & $F$ & $P$ & $F$ & $P$ & $F$ & $P$ \\
\hline \multicolumn{12}{|l|}{ Fara cave } \\
\hline Position (Po) & 2 & 11.680 & $0.001^{* *}$ & 2.705 & 0.077 & 1.818 & 0.173 & 0.365 & 0.696 & 0.521 & 0.597 \\
\hline Distance (Di) & 7 & 6.504 & $0.001^{* *}$ & 5.699 & $0.001^{* *}$ & 7.020 & $0.001^{* *}$ & 3.192 & $0.007^{* *}$ & 7.809 & $0.000^{* *}$ \\
\hline $\mathrm{Po} \times \mathrm{Di}$ & 14 & 4.856 & $0.001^{* *}$ & 4.130 & $0.001^{* *}$ & 3.061 & $0.002^{* *}$ & 2.293 & $0.017^{*}$ & 4.600 & $0.000^{* *}$ \\
\hline Total & 72 & & & & & & & & & & \\
\hline \multicolumn{12}{|l|}{ Agios Vasilios cave } \\
\hline Position (Po) & 2 & 0.487 & 0.619 & 2.369 & 0.111 & 1.186 & 0.319 & 3.795 & $0.034^{*}$ & 2.068 & 0.144 \\
\hline Distance (Di) & 4 & 20.266 & $0.001^{* *}$ & 20.258 & $0.001^{* *}$ & 2.327 & 0.079 & 0.379 & 0.822 & 1.077 & 0.385 \\
\hline $\mathrm{Po} \times \mathrm{Di}$ & 8 & 4.285 & $0.02^{*}$ & 4.746 & $0.001^{* *}$ & 0.737 & 0.658 & 2.320 & $0.045^{*}$ & 1.783 & 0.120 \\
\hline Total & 45 & & & & & & & & & & \\
\hline
\end{tabular}


Table 4. Spearman's rank correlation coefficient of morphological diversity with species richness $(\mathrm{S})$ and diversity $\left(\mathrm{H}^{\prime}\right)$ in the studied caves $\left({ }^{* *}\right.$ significance at the 0.01 level).

\begin{tabular}{llllll}
\hline Cave & Fara & & \multicolumn{2}{c}{ Agios Vasilios } \\
\cline { 2 - 3 } \cline { 6 - 7 } & S & H' & & S & H' \\
\hline Spearman's rho & 0.669 & 0.7 & & 0.556 & 0.477 \\
Sig. (2-tailed) & $0.000^{* *}$ & $0.000^{* *}$ & & $0.000^{* *}$ & $0.001^{* *}$ \\
N & 72 & 72 & & 45 & 45 \\
\hline
\end{tabular}

and opposite vertical walls) and showed that this topographic factor played a significant role in assemblage structure. Heterogeneity within particular cave sectors has been rarely investigated in the past. A limited number of studies has revealed differences in the structure of sessile communities between opposite vertical walls (Dellow \& Cassie, 1955), walls vs cave bottoms (Russ \& Rützler, 1959), different depth levels on vertical walls (Bell, 2002), or sites on the walls within cave sectors (Bussotti et al., 2006). In certain cases, the magnitude of such variations within a single cave was greater than that observed among different caves (Dellow \& Cassie, 1955; Bussotti et al., 2006), thus highlighting the effect of internal cave topography on the structure of cave assemblages.

Divergent patterns of sponge diversity were found in the surveyed caves. Previous studies concerning the animaldominated communities of western Mediterranean caves also revealed divergent patterns of spatial variability: in some caves, S, H' and sponge coverage decreased inwards (Pansini et al., 1977; Balduzzi et al., 1989; Marti et al., 2004a, b), while in other cases the above measures increased from the entrance to the middle (Sará, 1962; Cinelli et al., 1977; Corriero et al., 1997, 2000; Bell, 2002), and even to the innermost cave sectors (Marti et al., 2004a, b). The aforementioned researchers generally agree that the higher values of diversity in the middle cave sectors, compared with the outer entrance zone is related to the elimination of light and the resulting disappearance of space-competing macroalgae; the decreasing trend inwards, on the other hand, is probably related to the reduction in trophic resources due to weak

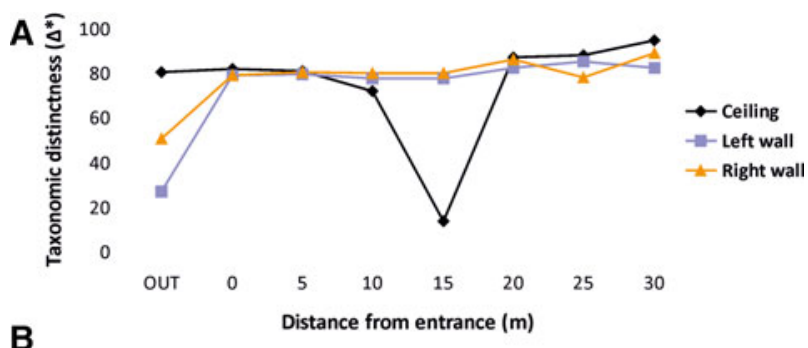

B

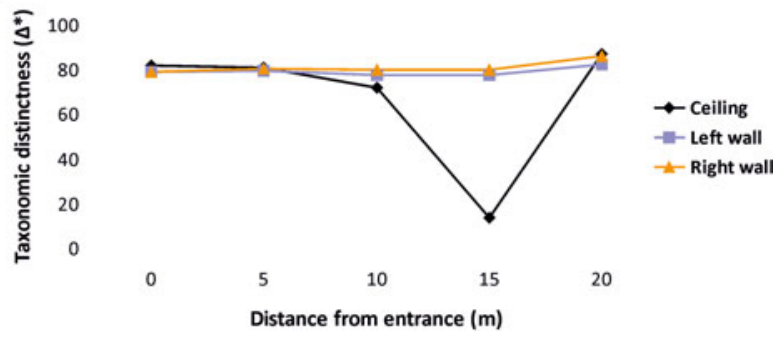

Fig. 5. Phylogenetic diversity calculated as taxonomic distinctness $\left(\Delta^{*}\right)$ along Fara (A) and Agios Vasilios caves (B) water movement. Ultimately, differences in diversity patterns among caves are attributed to cave-specific topographic features generating gradients of abiotic and biotic parameters (Balduzzi et al., 1989; Bell, 2002; Marti et al., 2004a, b; Bussotti et al., 2006).

The two surveyed caves are characterized by different topographic features (e.g. depth, shape, and size of entrance), which presumably affect light penetration and water circulation. It is noteworthy that in the tunnel-shaped Fara cave, all diversity measures steeply decreased between 5 and $20 \mathrm{~m}$ from the entrance and then slightly increased towards the inner cave end. The diversity patterns observed in Fara can be reasonably related to the variation of the cross-sectional area along the horizontal axis of the cave and the associated hydrodynamic factors. Underwater tunnels are characterized by stronger water flow compared with blind caves, and this situation is often reflected in the structure of their assemblages (Riedl, 1966; Harmelin, 1969; Vacelet, 1976; Harmelin et al., 1985). Indeed, in our case, during underwater fieldwork, the existence of a mild inward current (stronger during heavy sea conditions) was detected in the cave interior. Pansini et al. (1977) suggested that the dominance of a few encrusting sponges along the middle corridor of a semi-submerged cave on Ischia Island (Tyrrhenian Sea) manifested the increasing level of hydrodynamics due to the Venturi effect (i.e. velocity of the fluid increases as the cross-sectional area decreases). Bell (2002), in a study of the sponge assemblage of a temperate semi-submerged cave in Ireland, also suggested that spatial variation of $\mathrm{S}, \mathrm{H}^{\prime}$, and $\mathrm{MD}$ was partially related to high flow rates, due to the cave narrowing. On the other hand, Agios Vasilios is a blind funnel-shaped cave exhibiting decreasing trends in diversity inwards, in accordance with previous studies in marine caves with similar morphology (e.g. Marti et al., 2004a). Blind caves (also known as 'cul-de-sac' caves) are generally characterized by a notable depletion of trophic resources due to increasing water confinement inwards, which results in progressive decrease of biotic coverage, biomass and diversity and the disappearance of massive growth-forms (Bianchi \& Morri, 1994). Our results, coupled with the findings of the aforementioned studies, stress the necessity of establishing monitoring schemes for representative Mediterranean cave types in order to promote the understanding of the underlying factors that shape community structure divergence.

Species evenness in the inner parts of the two surveyed caves was generally higher compared with that in their outer sectors, indicating that sponge species were more evenly distributed in the cave interior and that no species dominated the corresponding assemblage, in accordance with other cave studies (Balduzzi et al., 1989; Bell, 2002; Barnes \& Bell, 2002b). Interestingly, S and $\mathrm{H}^{\prime}$ were significantly positively correlated with $\mathrm{MD}$ in the studied caves in spite of their contrasting diversity patterns. Bell \& Barnes (2002) found no significant correlation between the aforementioned diversity measures in tropical caves of the West Indian Ocean, due to the dominance of encrusting forms. Nevertheless, this model had not been tested up to date in temperate marine caves. Filling this gap, our results suggest that MD could possibly be used as a surrogate measure for describing sponge diversity trends in Mediterranean marine caves. However, this should be examined in marine caves of different topography in various areas. The slight increment of TD towards the interior sectors of the studied caves corroborates that environmental stability in 
inner cave sectors might favour the development of a taxonomically broader sponge assemblage compared with exposed sublittoral substrates (Gerovasileiou \& Voultsiadou, 2012).

Sponges of particular growth forms presented higher coverage in specific sectors of the studied marine caves, possibly reflecting adaptation to local environmental conditions. For example, it has been suggested that the dominance of encrusting sponges in the dark inner cave sectors (Harmelin et al., 1985; Corriero et al., 2000; Barnes \& Bell, 2002a; Marti et al., 2004a; Bussotti et al., 2006; this study) reflects an adaptation to water confinement and reduced trophic resources; thinly encrusting forms exhibit a more effective filtration surface/volume ratio and can, therefore, exploit the rare particulate organic matter of the water (Bibiloni et al. 1989). The arborescent species Axinella cannabina and A. verrucosa presented greater coverage at the 5-10 $\mathrm{m}$ distance levels, on the left wall of Fara cave. A thin layer of sediment was constantly observed in this area during the dives, due to a locally higher sedimentation rate resulting from the positive wall inclination and the proximity to the muddy bottom. Erect sponges can cope better with high sedimentation levels as this growth form prevents sediment settlement and clogging of their aquiferous system (Bell et al., 2002 and references therein). Bibiloni et al. (1989) also reported the development of erect growth forms in cave sectors with high levels of sedimentation. On the other hand, boring species (Cliona spp.) were found only in the outer sectors of the studied caves, which were dominated by calcareous biogenic substrate (e.g. encrusting rhodophytes). Previous studies have shown that horizontal distribution of clionids in marine caves is related to the presence of suitable calcareous substrate (e.g. calcareous macroalgae, Balanus and Ostrea shells, and carbonate rocks) along the cave and the interactions with other organisms (Sará, 1962; Pansini et al., 1977; Balduzzi et al., 1989).

In conclusion, this quantitative study of marine cave sponge assemblages in the eastern Mediterranean basin filled regional gaps for an understudied habitat of special conservation interest. The results of the study highlighted (a) the spatial heterogeneity in the composition of sponge assemblages and (b) the presence of divergent sponge diversity gradients among marine caves with different morphology as well as in various microhabitats within these caves. Given that heterogeneity constitutes an important parameter for conservation actions, further research in representative marine cave types of the eastern Mediterranean is needed to enhance scientific knowledge of these ecosystems.

\section{ACKNDWLEDGEMENTS}

The authors would like to thank Maria Sini for her help during fieldwork and Charalampos Dimitriadis for assistance in statistical analysis. The first author is grateful to the organizing committee of the 9th World Sponge Conference.

\section{FINANCIAL SUPPORT}

This research has been co-financed by the EU and Greek national funds through the Research Funding Program: Heracleitus II, Investing in knowledge society. Vasilis Gerovasileiou also benefited from an 'Alexander S. Onassis Public Benefit Foundation' fellowship for postgraduate studies.

\section{REFERENCES}

Anderson M.J., Gorley R.N. and Clarke K.R. (2008) PERMANOVA for PRIMER: guide to software and statistical methods. Plymouth: PRIMER - E.

Balduzzi A., Bianchi C.N., Boero F., Cattaneo Vietti R., Pansini M. and Sarà M. (1989) The suspension-feeder communities of a Mediterranean sea cave. Scientia Marina 53, 387-395.

Barnes D.K.A. and Bell J.J. (2002a) Coastal sponge communities of the West Indian Ocean: morphological richness and diversity. African Journal of Ecology 40, 350-359.

Barnes D.K.A. and Bell J.J. (2002b) Coastal sponge communities of the West Indian Ocean: taxonomic affinities, richness and diversity. African Journal of Ecology 40, 337-349.

Bell J.J. (2002) The sponge community in a semi-submerged temperate sea cave: density, diversity and richness. Marine Ecology Pubblicazioni della Stazione Zoologica di Napoli I 23, 297-311.

Bell J.J. (2007) The use of volunteers for conducting sponge biodiversity assessments and monitoring using a morphological approach on IndoPacific coral reefs. Aquatic Conservation: Marine and Freshwater Ecosystems 17, 133-145.

Bell J.J. and Barnes D.K.A. (2001) Sponge morphological diversity: a qualitative predictor of species diversity? Aquatic Conservation: Marine and Freshwater Ecosystems 11, 109-121.

Bell J.J. and Barnes D.K.A. (2002) Modelling sponges species diversity using morphological predictor: a tropical test of temperate model. Journal of Nature Conservation 10, 41-50.

Bell J.J., Barnes D.K.A. and Shaw C. (2002) Branching dynamics of two species of arborescent demosponge: the effect of flow regime and bathymetry. Journal of the Marine Biological Association of the United Kingdom 82, 279-294.

Bianchi C.N. and Morri C. (1994) Studio bionomico comparativo di alcune grotte marine sommerse; definizione di una scala di confinamento. Memorie dell'Istituto italiano di Speleologia 6, 107-123.

Bianchi C.N. and Morri C. (2003) Global sea warming and 'tropicalization' of the Mediterranean Sea: biogeographic and ecological aspects. Biogeographia 24, 319-327.

Bianchi C.N., Pronzato R., Cattaneo-Vietti R., Benedetti-Cecchi L., Morri C., Pansini M., Chemello R., Milazzo M., Fraschetti S., Terlizzi A., Peirano A., Salvati E., Benzoni F., Calcinai B., Cerrano C. and Bavestrello G. (2004) Mediterranean marine benthos: a manual of methods for its sampling and study. Hard bottoms. Biologia Marina Mediterranea 11, 185-215.

Bibiloni M.A., Uriz M.J. and Gili J.M. (1989) Sponge communities in three submarine caves of the Balearic Islands (western Mediterranean): adaptations and faunistic composition. Marine Ecology - Pubblicazioni della Stazione Zoologica di Napoli I 10, 317-334.

Boury-Esnault N., Muricy G., Gallissian M.F. and Vacelet J. (1995) Sponges without skeleton: a new Mediterranean genus of Homoscleromorpha (Porifera, Demospongiae). Ophelia 43, 25-43.

Boury-Esnault N. and Rützler K. (1997) Thesaurus of sponge morphology. Smithsonian Contributions to Zoology 596, 1- 55 .

Bussotti S., Terlizzi A., Fraschetti S., Belmonte G. and Boero F. (2006) Spatial and temporal variability of sessile benthos in shallow Mediterranean marine caves. Marine Ecology Progress Series 325, 109-119.

Cinelli F., Fresi E., Mazzella L., Pansini M., Pronzato R. and Svoboda A. (1977) Distribution of benthic phyto- and zoocoenoses along a light gradient in a superficial marine cave. In Keegan B.F., Ceidigh P.O. and Boaden P.J.S. (eds) Proceedings of the Eleventh European Symposium on Marine Biology, University College, Galway, 5-11 
October 1976. Biology of benthic organisms. Oxford: Pergamon Press, pp. $173-183$.

Clarke K.R. and Gorley R.N. (2006) PRIMER v6: user manual/tutorial. Plymouth: PRIMER - E.

Clarke K.R. and Warwick R.M. (1998) A taxonomic distinctness index and its statistical properties. Journal of Applied Ecology 35, 523-531.

Corriero G., Liaci L.S., Ruggiero D. and Pansini M. (2000) The sponge community of a semi-submerged Mediterranean cave. Marine Ecology - Pubblicazioni della Stazione Zoologica di Napoli I 21, 85-96.

Corriero G., Scalera Liaci L., Gristina M., Riggio S. and Mercurio M. (1997) Composizione tassonomica e distribuzione della fauna a poriferi e briozoi in una grotta semisommersa della Riserva Naturale Marina "Isola di Ustica". Biologia Marina Mediterranea 4, 34-43.

Dellow V. and Cassie R.M. (1955) Littoral zonation in two caves in the Auckland district. Transactions of the Royal Society of New Zealand $83,321-331$.

Gerovasileiou V., Chintiroglou C., Vafidis D., Koutsoubas D., Sini M., Dailianis T., Issaris Y., Akritopoulou E., Dimarchopoulou D. and Voultsiadou E. (2015a) Census of biodiversity in marine caves of the Eastern Mediterranean Sea. Mediterranean Marine Science 16, $245-265$.

Gerovasileiou V., Trygonis V., Sini M., Koutsoubas D. and Voultsiadou E. (2013) Three-dimensional mapping of marine caves using a handheld echosounder. Marine Ecology Progress Series 486, 13-22.

Gerovasileiou V. and Voultsiadou E. (2012) Marine caves of the mediterranean sea: a sponge biodiversity reservoir within a biodiversity hotspot. PLoS ONE 7, e39873. doi: 10.1371/journal.pone.0039873

Gerovasileiou V. and Voultsiadou E. (2014) Mediterranean marine caves as biodiversity reservoirs: a preliminary overview. In Symposia on the conservation of Mediterranean marine key habitats, Portorož, 27-31 October 2014. Tunis: RAC/SPA, pp. 45-50.

Gerovasileiou V., Voultsiadou E., Issaris Y. and Zenetos A. (2015b) Alien biodiversity in Mediterranean marine caves. Marine Ecology, doi: $10.1111 / \mathrm{maec} .12268$.

Harmelin J.G. (1969) Bryozoaires des grottes sous-marines obscures de la région marseillaise, faunistique et écologie. Téthys 1, 793-806.

Harmelin J.G., Vacelet J. and Vasseur P. (1985) Les grottes sous-marines obscures: un milieu extrême et un remarquable biotope refuge. Téthys 11, 214-229.

Hooper J.N.A. and Van Soest R.W.M. (2002) Systema Porifera. A guide to the classification of sponges. New York: Kluwer Academic/Plenum Publishers.

Kipson S., Fourt M., Teixidó N., Cebrian E., Casas E., Ballesteros E., Zabala M. and Garrabou J. (2011) Rapid biodiversity assessment and monitoring method for highly diverse benthic communities: a case study of Mediterranean coralligenous outcrops. PLOS ONE 6, e27103. doi: 10.1371/journal.pone.0027103

Maldonado M. and Young C.M. (1996) Bathymetric patterns of sponge distribution on the Bahamian slope. Deep Sea Research 43, 897-915.

Martí R., Uriz M.J., Ballesteros E. and Turón X. (2004a) Benthic assemblages in two Mediterranean caves: species diversity and coverage as a function of abiotic parameters and geographic distance. Journal of the Marine Biological Association of the United Kingdom 84, 557-572.

Martì R., Uriz M.J., Ballesteros E. and Turon X. (2004b) Temporal variation of several structure descriptors in animal dominated benthic communities in two Mediterranean caves. Journal of the Marine Biological Association of the United Kingdom 84, 573-580.

Pansini M., Pronzato R., Fresi E., Cinelli F., Mazzella L. and Ponticelli M. (1977) Evoluzione delle biocenosi bentoniche di substrato duro lungo un gradiente di luce in una grotta marina superficiale. In Fresi E. and Cinell
F. (eds) Atti del IX Congresso della Società Italiana di Biologia Marina, Lacco Ameno d'Ischia, 19-22 May 1977. Firenze: La Seppia,pp. 315-330.

Parravicini V., Guidetti P., Morri C., Montefalcone M., Donato M. and Bianchi C.N. (2010) Consequences of sea water temperature anomalies on a Mediterranean submarine cave ecosystem. Estuarine, Coastal and Shelf Science 86, 276-282.

Pisera A. and Vacelet J. (2011) Lithistid sponges from submarine caves in the Mediterranean: taxonomy and affinities. Scientia Marina 75 , $17-40$.

Pouliquen L. (1972) Les spongiaires des grottes sous-marines de la région de Marseille. Ecologie et systématique. Téthys 3, 717-758.

Riedl R. (1966) Biologie der Meereshöhlen. Hamburg: Paul Parey.

Russ K. and Rützler K. (1959) Zur Kenntnis der Schwammfauna unterseeischer Höhlen. Pubblicazioni della Stazione Zoologica di Napoli 30 , $756-787$.

Rützler K., Piantoni C., Van Soest R.W.M. and Díaz C.M. (2014) Diversity of sponges (Porifera) from cryptic habitats on the Belize barrier reef near Carrie Bow Cay. Zootaxa 3805, 1-129.

Sará M. (1961) Zonazione dei poriferi nella grotta della "Gaiola". Annuario del Museo Zoologico della Università di Napoli 13, 1-32.

Sará M. (1962) Zonazione dei Poriferi in biotopi litorali. Pubblicazion della Stazione Zoologica di Napoli 32, 44-57.

Schönberg C.H.L. and Fromont J. (2013) Functional sponge morphologies. In Edwards L. (ed.) CATAMI classification scheme for scoring marine biota and substrata in underwater imagery. Technical Report. http://catami.org/classification.

Trygonis V. and Sini M. (2012) photoQuad: a dedicated seabed image processing software, and a comparative error analysis of four photoquadrat methods. Journal of Experimental Marine Biology and Ecology 424-425, 99-108.

UNEP-MAP-RAC/SPA (2015) Action plan for the conservation of habitats and species associated with seamounts, underwater caves and canyons, aphotic hard beds and chemo-synthetic phenomena in the Mediterranean Sea. Dark Habitats Action Plan. Tunis: RAC/SPA.

Vacelet J. (1976) Les Spongiaires des grottes sous-marines obscures de la Méditerranée et des régions tropicales. Pubblicazioni della Stazione Zoologica di Napoli 40, 506-515.

Vacelet J. and Boury-Esnault N. (1996) A new species of carnivorous sponge (Demospongiae: Cladorhizidae) from a Mediterranean cave. Bulletin de l'Institut Royal des Sciences Naturelles de Belqique 66, 109-115.

Vacelet J. and Lévi C. (1958) Un cas de survivance, en Méditerranée, du groupe d'éponges fossiles des Pharétronides. Comptes Rendus Hebdomadaires des Séances de l'Académie des Sciences 246, 318-320.

Van Soest R.W.M., Boury-Esnault N., Hooper J.N.A., Rützler K., de Voogd N.J., Alvarez de Glasby B., Hajdu E., Pisera A.B., Manconi R., Schoenberg C., Janussen D., Tabachnick K.R., Klautau M., Picton B., Kelly M., Vacelet J., Dohrmann M., Díaz M.-C. and Cárdenas P. (2015) World Porifera database. http://www.marine species.org/porifera.

and

Warwick R.M. and Clarke K.R. (1995) New 'biodiversity’ measures reveal a decrease in taxonomic distinctness with increasing stress. Marine Ecology Progress Series 129, 301-305.

\section{Correspondence should be addressed to:}

V. Gerovasileiou

Institute of Marine Biology, Biotechnology and Aquaculture, Hellenic Centre for Marine Research, Heraklion, Crete, Greece email: vgerovas@hcmr.gr 